\title{
Toxicity of Depressant and Antidepressant Drugs in Hyperthyroid Mice
}

\author{
A. ASHFORD,* PH.D. ; JANET W. ROSS,* B.SC.
}

Brit. med. F., 1968, 2, 217-218

It is evident from the literature that there is a relation between thyroid hormones and the toxicity of drugs and other chemical substances. The administration of thyroxine or desiccated thyroid to various animal species is reported to increase susceptibility to the toxic effects of the following compounds: alloxan (Houssay and Sara, 1945), endotoxin (Kroneberg and Pötzsch, 1952), cocaine, $o$-dinitrophenol, and dinitro-o-cresol (Glaubach and Pick, 1931, 1934), morphine (Hunt and Seidell, 1910), adrenaline (Kroneberg and Hüter, 1951), ephedrine (Halpern, Drudi-Baracco, and Bessirard, 1964), amphetamine (Moore, 1965), a non-hydrazide monoamine oxidase inhibitor (Carrier and Buday, 1961), and imipramine (Prange and Lipton, 1962). There is less evidence concerning the toxicity of drugs in the hypothyroid state; a search of the literature showed references to only two substances. The toxicity of imipramine was reported to be lower in mice in which thyroid function had been reduced by treatment with propylthiouracil (Prange, Lipton, and Love, 1963), though this was not confirmed by later studies (Prange, Lipton, and Love, 1964), and the toxicity of alloxan was reduced in thyroidectomized rats (Houssay and Sara, 1945).

The purpose of this paper is to report on the toxicity of several widely used antidepressant and tranquillizer drugs in mice made hyperthyroid by the addition of desiccated thyroid to the diet, and to draw attention to possible hazards in their use in the hyperthyroid state in man.

\section{Methods}

Experiments were carried out on female CFW mice of 16-18 g. body weight housed in groups of five at a room temperature of $21^{\circ} \mathrm{C}$. For six days the animals had free access to food and water, the diet of the thyroid-treated groups being supplemented with $2 \% \mathrm{w} / \mathrm{w}$ of dried thyroid. The presence of the hyperthyroid state was checked at the end of six days by measuring the oxygen consumption, at $26^{\circ} \mathrm{C}$., of several groups of two animals by the method of Tomich and Woollett (1954).

Tests were carried out on the following drugs, which were given by mouth to mice starved for at least two hours: nortriptyline, imipramine, chlorpromazine, and chlordiazepoxide as the hydrochloride, and perphenazine, meprobamate, and reserpine as the base. The vehicle was $0.5 \%$ tragacanth except in the case of reserpine, which was dissolved in a mixture of citric acid, benzyl alcohol, and Tween 80 (polysorbate 80 ).

The toxicity of the drugs was first established in normal and hyperthyroid mice, and then the effect of pretreatment with saline, the $\alpha$-adrenergic blocking agent phenoxybenzamine (15 mg. $/ \mathrm{kg}$. subcutaneously), or the $\beta$-adrenergic antagonist pronethalol (10 mg. $/ \mathrm{kg}$. subcutaneously) was investigated. Pretreatment times are given in the Tables. The effectiveness of phenoxybenzamine and pronethalol, at the dose level used, was demonstrated by (a) preventing the toxic effect of intravenous adrenaline with phenoxybenzamine and $(b)$ reducing heart rate in hyperthyroid animals with pronethalol. Both drugs were effective. There were five mice per group unless - Pharmacology Department, Twyford Laboratories Ltd., London
N.W.10. otherwise stated. The injection volume was $0.2 \mathrm{ml} . / 20 \mathrm{~g}$. and the animals were observed at intervals for a period of 24 hours.

\section{Results}

After six days on the thyroid-supplemented diet the mice were not grossly different in appearance from controls, and body weight was the same in both groups. However, the oxygen consumption of the thyroid-treated mice was signifcantly greater than that of controls (Table I).

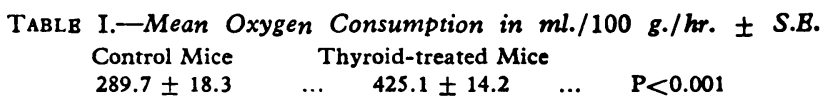

With the exception of meprobamate and reserpine all the drugs tested were considerably more toxic in thyroid-treated than in normal animals. This can be clearly seen in Table II, but it is difficult to determine precisely the degree by which toxicity was increased, since the top doses given, though high, were generally sublethal in normal animals. Nortriptyline showed the greatest increase, being at least 25 times more toxic in hyperthyroid mice than in normal controls.

Hyperthyroid mice treated with nortriptyline or imipramine showed profuse salivation and bursts of marked hyperactivity

\begin{tabular}{|c|c|c|c|}
\hline \multirow{2}{*}{ Drug } & \multirow{2}{*}{$\begin{array}{c}\text { Dose } \\
\text { (mg./kg. } \\
\text { p.o.) }\end{array}$} & \multicolumn{2}{|c|}{ Percentage Dead in 24 Hours } \\
\hline & & Controls & Thyroid Treated \\
\hline Nortriptyline .. & $\begin{array}{c}150.0 \\
75 \cdot 0 \\
37.5 \\
18 \cdot 75 \\
9.5 \\
4.75 \\
2.5\end{array}$ & $\begin{array}{c}0 \\
20 \\
0 \\
0 \\
0 \\
0 \\
0 \\
0 \\
\text { LD }_{s 0}>150 \mathrm{mg} . / \mathrm{kg} .\end{array}$ & $\begin{array}{c}100 \\
100 \\
100 \\
80 \\
100 \\
60 \\
0 \\
\text { LD }_{50}=5 \cdot 4 \mathrm{mg} . / \mathrm{kg} . \\
(3 \cdot 2 \text { to } 9 \cdot 2) \\
\end{array}$ \\
\hline Imipramine $\quad .$. & $\begin{array}{c}250 \cdot 0 \\
125 \cdot 0 \\
62.5 \\
31 \cdot 25 \\
15 \cdot 6\end{array}$ & $\begin{array}{c}20 \\
0 \\
0 \\
0 \\
0 \\
\text { LD }_{50}>250 \mathrm{mg} . / \mathrm{kg} .\end{array}$ & $\begin{array}{c}100 \\
80 \\
80 \\
20 \\
0 \\
\mathrm{LD}_{50}=50 \mathrm{mg} . / \mathrm{kg} . \\
(31.25 \text { to } 80) \\
\end{array}$ \\
\hline Chlorpromazine & $\begin{array}{l}250 \cdot 0 \\
125 \cdot 0 \\
62 \cdot 5 \\
31 \cdot 25 \\
15 \cdot 6\end{array}$ & $\begin{array}{c}20 \\
0 \\
0 \\
20 \\
0 \\
L_{\text {so }}>250 \mathrm{mg} . / \mathrm{kg} .\end{array}$ & $\begin{array}{c}100 \\
70 \\
80 \\
40 \\
0 \\
\text { LD }_{50}=36.5 \mathrm{mg} . / \mathrm{kg} . \\
(18.25 \text { to } 73) \\
\end{array}$ \\
\hline Perphenazine .. & $\begin{array}{r}120 \cdot 0 \\
60 \cdot 0 \\
30 \cdot 0 \\
15 \cdot 0\end{array}$ & $\begin{array}{c}u \\
u \\
0 \\
L^{0} \\
>120 \mathrm{mg} . / \mathrm{kg} .\end{array}$ & $\begin{array}{c}80 \\
40 \\
60 \\
0 \\
\mathrm{LD}_{50}=50 \mathrm{mg} . / \mathrm{kg} . \\
(22 \cdot 7 \text { to } 110) \\
\end{array}$ \\
\hline Chlordiazepoxide & $\begin{array}{r}800 \cdot 0 \\
400 \cdot 0 \\
200 \cdot 0 \\
100 \cdot 0 \\
50 \cdot 0\end{array}$ & $\begin{array}{c}20 \\
0 \\
0 \\
0 \\
0 \\
\text { LD }_{50}>\mathbf{8 0 0} \mathrm{mg} . / \mathrm{kg} .\end{array}$ & $\begin{array}{c}100 \\
80 \\
60 \\
6 J \\
0 \\
\mathrm{LD}_{50}=122 \mathrm{mg} . / \mathrm{kg} . \\
(50 \cdot 8 \text { to } 292 \cdot 8) \\
\end{array}$ \\
\hline Meprobamate .. & $\begin{array}{r}800 \cdot 0 \\
400 \cdot 0 \\
\end{array}$ & $\begin{array}{l}0 \\
0 \\
\end{array}$ & $\begin{array}{r}20 \\
0\end{array}$ \\
\hline Reserpine & $\begin{array}{r}50 \cdot 0 \\
25 \cdot 0 \\
2.5\end{array}$ & $\begin{array}{l}\overline{0} \\
0\end{array}$ & $\begin{array}{r}0 \\
20 \\
0\end{array}$ \\
\hline
\end{tabular}


which alternated with periods of quiescence. Death appeared to be related to the degree of stimulation. Apart from slight salivation at high dose-levels of nortriptyline these effects were not seen in controls, which either remained normal or showed slight sedation.

Chlorpromazine, perphenazine, chlordiazepoxide, and reserpine caused profound sedation, which developed more quickly and was of longer duration in hyperthyroid than in normal mice, whereas meprobamate caused sedation or loss of righting reflex to about the same degree in both groups. It was interesting to note that the phase of increased motor activity which precedes sedation in normal animals treated with meprobamate and chlordiazepoxide was not observed in hyperthyroid mice. Slight salivation was evident in hyperthyroid mice that received the highest doses of chlordiazepoxide.

In view of the large number of reports which link the symptoms of hyperthyroidism with a state of heightened sensitivity to catecholamines (review by Harrison, 1964), and in view of the known cocaine-like action of imipramine and chlorpromazine (Axelrod, Whitby, and Hertting, 1961), we attempted to modify drug toxicity in hyperthyroid mice by pretreatment with an $\alpha$ - or $\beta$-adrenergic blocking agent. The results (Table III) indicate that neither phenoxybenzamine nor pronethalol reduced toxicity.

TABLE III.-Effect of Pretreatment with Saline, Phenoxybenzamine, or Pronethalol, Given Subcutaneously 30 Minutes Before Treatment, on Toxicity in Hyperthyroid and Control Mice

\begin{tabular}{|c|c|c|c|c|c|c|c|c|}
\hline \multirow[b]{3}{*}{ Drug } & & \multirow[b]{3}{*}{$\begin{array}{c}\text { Dose } \\
\text { (mg./kg. } \\
\text { p.o.) }\end{array}$} & \multicolumn{6}{|c|}{ Percentage Dead in 24 Hours } \\
\hline & & & \multicolumn{3}{|c|}{ Hyperthyroid Mice } & \multicolumn{3}{|c|}{ Controls } \\
\hline & & & 节 & 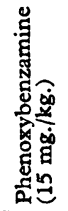 & 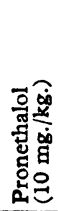 & 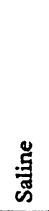 & 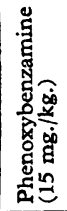 & 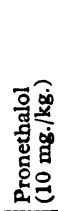 \\
\hline Nortriptyline & .. & $\begin{array}{l}50.0 \\
40.0 \\
25.0\end{array}$ & $\begin{array}{r}100 \\
60 \\
80\end{array}$ & $\begin{array}{r}100 \\
20 \\
70\end{array}$ & $\frac{100}{100}$ & $\begin{array}{l}0 \\
0 \\
0\end{array}$ & $\begin{array}{l}0 \\
0 \\
-\end{array}$ & $\frac{0}{0}$ \\
\hline Imipramine & .. & $\begin{array}{r}125.0 \\
62.5 \\
50.0\end{array}$ & $\begin{array}{r}100 \\
60 \\
20\end{array}$ & $\begin{array}{r}100 \\
90 \\
20\end{array}$ & 100 & $\frac{0}{0}$ & $\frac{0}{0}$ & $\underline{0}$ \\
\hline Chlorpromazine & $\cdots$ & $\begin{array}{r}125 \cdot 0 \\
62.5\end{array}$ & $\begin{array}{r}80 \\
100\end{array}$ & $\begin{array}{l}100 \\
100\end{array}$ & 100 & $\underline{0}$ & 20 & $\underline{0}$ \\
\hline Perphenazine & .. & $\begin{array}{r}125.0 \\
62.5\end{array}$ & $\begin{array}{l}80 \\
60\end{array}$ & $\begin{array}{l}100 \\
100\end{array}$ & $\begin{array}{l}60 \\
40\end{array}$ & $\begin{array}{l}0 \\
0\end{array}$ & $\underline{0}$ & $\begin{array}{l}0 \\
0\end{array}$ \\
\hline $\begin{array}{l}\text { Chlordiazepoxide } \\
\text { Control } \quad \text {. }\end{array}$ & $\therefore$ & $400 \cdot 0$ & 100 & $\begin{array}{r}100 \\
0\end{array}$ & $\begin{array}{r}100 \\
0\end{array}$ & 二 & 二 & $=$ \\
\hline
\end{tabular}

\section{Discussion}

The results clearly show an increase in the toxicity of some drugs in animals treated with excessive amounts of thyroid hormones. Though the secretion of thyrotropin in human hyperthyroidism may differ from that in mice fed on a diet containing thyroid, induction by dietary means largely reproduces the extrathyroidal aspects of human thyrotoxicosis (Drill, 1965), and the findings in mice may therefore be equally valid in man. It is recognized that use of antidepressant drugs in the therapy of thyrotoxicosis is unlikely, but the phenothiazines and reserpine are sometimes prescribed. In view of the results given in this paper the phenothiazines, and possibly other drugs, should be used with caution, since the safety margin may be reduced, and indeed it might be possible to achieve a satisfactory degree of sedation in hypenthyroid patients with a dose lower than that necessary in euthyroid patients.

The mechanism by which drug toxicity is increased is obscure. Heightened sensitivity to catecholamines has been a cardinal feature of the literature on hyperthyroidism for many years (Harrison, 1964) and may possibly be involved. However, recent reports have cast doubt on the thyroid-adrenaline relation (Margolius and Gaffney, 1965 ; van der Schoot and Moran, 1965), and it is clear that the increased toxic action of the drugs we have tested in hyperthyroid mice is not attributable to either an $\alpha$ or $\beta$ action of adrenaline, since the relevant blocking agents, phenoxybenzamine and pronethalol, did not reduce toxicity. In any case chlorpromazine possesses intrinsic $\alpha$-blocking properties (Goodman and Gilman, 1965a).

Another possible mechanism involves adrenocortical hormones. Spencer and West (1963) postulated a mutual antagonism between these hormones and those of the thyroid gland. An excess of the latter induces a relative deficiency of glucoconticoids owing to an increase in tissue demands (Peterson, 1958). This could lead to a non-specific increase in the sensitivity of the organism to noxious stimuli (Goodman and Gilman, 1965b) and might better explain why drugs of such different types show increased toxic effects in hyperthyroidism.

\section{Summary}

Imipramine, nortriptyline, chlorpromazine, perphenazine, and chlordiazepoxide were more toxic in hypenthyroid than in normal mice, whereas the toxicity of meprobamate and reserpine was not enhanced. The increase in toxicity was not prevented by pretreatment with an $\alpha$ - or $\beta$-adrenergic blocking agent. All the sedative drugs appeared to have a greater depressant effect in hyperthyroid than in normal mice. It is suggested that the safety margin of phenothiazines, and possibly other drugs, may be reduced in uncontrolled hyperthyroidism in man.

\section{REFERENCES}

Axelrod, J., Whitby, L. G., and Hertting, G. (1961). Science, 133, 383. Carrier, R. N., and Buday, P. V. (1961). Nature (Lond.), 191, 1107.

Drill, V. A. (1965). Pharmacology in Medicine, 3rd ed., edited by J. R. DiPalma, p. 1137. New York.

Glaubach, S., and Pick, E. P. (1931). Arch. exp. Path. Pharmak., 162, 537.

Glaubach, S., and Pick, E. P. (1934). Schweiz. med. Wschr., 64, 1115.

Goodman, L. S., and Gilman, A. (editors) (1965a). The Pharmacological Basis of Therapeutics, 3rd ed., p. 171. New York.

Goodman, L. S., and Gilman, A. (editors) (1965b). The Pharmacological Basis of Therapeutics, p. 1617.

Halpern, B. N., Drudi-Baracco, C., and Bessirard, D. (1964). Nature (Lond.), 204, 387.

Harrison, T. S. (1964). Physiol. Rev., 44, 161.

Houssay, B. A., and Sara, J. G. (1945). Rev. Soc. argent. Biol., 21, 81.

Hunt, R., and Seidell, A. (1910). 7. Pharmacol. exp. Ther., 2, 15.

Kroneberg, G., and Hüter, F. (1951). Klin. Wschr., 29, 649.

Kroneberg, G., and Pötzsch, E. (1952). Arch. exp. Path. Pharmak., 216, 233.

Margolius, H. S., and Gaffney, T. E. (1965). F. Pharmacol. exp. Ther., $149,329$.

Moore, K. E. (1965). Biochem. Pharmacol., 14, 1831.

Peterson, R. E. (1958). F. clin. Invest., 37, 736.

Prange, A. J., and Lipton, M. A. (1962). Nature (Lond.), 196, 588.

Prange, A. J., Lipton, M. A., and Love, G. N. (1963). Nature (Lond.), 197,1212 .

Prange, A. J., Lipton, M. A., and Love, G. N. (1964). Nature (Lond.), 204, 1204.

Spencer, P. S. J., and West, G. B. (1963). Nature (Lond.), 199, 1298.

Tomich, E. G., and Woollett, E. A. (1954). f. Endocr., 11, 134.

van der Schoot, J. B., and Moran, N. C. (1965). F. Pharmacol. oxp. Ther., $149,336$. 